\title{
Władca idealny według „Księgi o władzy”, pierwszej części Kitāb al-ciqd al-farīd Ibn 'Abd Rabbiha
}

\author{
The Perfect Ruler According to the "Book of the Sovereign Power”, \\ Chapter One of the Kitāb Al-clqd al-Farīd by Ibn ' ${ }^{\mathrm{A}}$ Abd Rabbih
}

\begin{abstract}
The purpose of this paper is to shed some new light on the role of the male character in medieval Arabic literature. It focuses on the model of the ruler which features in Andalusian adab literature in $A l^{-} I q d$ al-Farid, a work of Ibn 'Abd Rabbih. The description of the ruler's powers, privileges, tasks, and duties are included in the first chapter of the work, which is a typical example of paraenetic literature outlining specific patterns of conduct related to one's position. Presenting the model ruler, Ibn ${ }^{\mathrm{C}} \mathrm{Abd}$ Rabbih used the same sources that were known in the East and selected those that, in his opinion, made up the image of a perfect ruler. The fundamental features of the ruler described in his work indicate that there were some universal attributes of the dynast in the Middle Ages.
\end{abstract}

Keywords: adab literature, the model of medieval ruler, Ibn ${ }^{\mathrm{c}} \mathrm{Abd}$ Rabbih, Al-c Iqd al-Farīd

\begin{abstract}
Abstrakt: Celem niniejszego artykułu jest rzucenie nowego światła na rolę postaci męskich w średniowiecznej literaturze arabskiej. Koncentruje się on na przedstawieniu modelu władcy, który pojawia się w andaluzyjskiej literaturze adabowej - w Al- ${ }^{c} I q d$ al-farìd, dziele Ibn ${ }^{\mathrm{c}} \mathrm{Abd}$ Rabbiha. Opis uprawnień, przywilejów, zadań i obowiązków władcy znajduje się w pierwszym rozdziale pracy, która jest typowym przykładem literatury parenetycznej i w której zarysowano specyficzne wzorce zachowań związane z zajmowanym stanowiskiem. Przedstawiając wzorowego władcę, Ibn 'Abd Rabbih skorzystał z tych samych źródeł, które były znane na Wschodzie, i wybrał te, które jego zdaniem składały się na wizerunek doskonałego władcy. Opisane w jego dziele fundamentalne cechy władcy wskazują na to, że w średniowieczu istniały pewne uniwersalne atrybuty dynasty.
\end{abstract}

Słowa kluczowe: literatura adabowa, model średniowiecznego władcy, Ibn ${ }^{\mathrm{c}} \mathrm{Abd}$ Rabbih, $\mathrm{Al}$ -cIqd al-farīd 
Nie ulega wątpliwości, że średniowieczna literatura arabska zdominowana jest przez mężczyzn, będących zarówno jej twórcami, bohaterami, jak i głównymi odbiorcami. To właśnie ten fakt sprawił, że badania nad szeroko pojętym wizerunkiem mężczyzny mogą wydawać się pozornie zaniedbane w porównaniu $\mathrm{z}$ analogicznymi badaniami nad postaciami i rolami kobiet w literaturze czy społeczeństwie średniowiecznego kalifatu. Ich obraz bowiem, jako rzadkość, budził naturalne zainteresowanie, a i profil poświęconych im badań sprzyjał podkreślaniu znaczenia, wizerunku, miejsca czy pozycji kobiety w średniowieczu. De facto - przytłaczająca większość badań skoncentrowana jest jednak na dziele i roli mężczyzn jako agensów i podmiotów średniowiecznego piśmiennictwa arabskiego. Niemniej - jest faktem i to, że studia nad wizerunkiem mężczyzny jako takiego, dotyczące jego znaczenia, roli, pozycji w społeczeństwie i wielu innych podobnych aspektów, mogą skutkować niezwykle inspirującymi spostrzeżeniami.

Spośród różnych postaw, modeli czy wzorców męskich obecnych w średniowiecznej literaturze arabskiej niewątpliwie na plan pierwszy, obok mędrca czy wojownika, wyłania się model władcy. Władca ogólnie archetypicznie wiąże się z pierwiastkiem męskim.

Celem niniejszych badań jest przedstawienie modelu władcy, który został ukształtowany w średniowiecznej literaturze andaluzyjskiej na podstawie wzorców wschodnich, wskazanie na potencjalne źródła takiego, a nie innego modelu oraz refleksja - na ile można mówić o pewnym uniwersalnym paradygmacie dynasty.

Wzorzec modelowego władcy zaczęto budować w okresie przedmuzułmańskim, określając wówczas najistotniejsze cechy szlachetnego, odważnego mężczyzny poprzez chwalebny zestaw działań, czynów i postaw mieszczący się w zasadach ğăhiliyskiej murū'a i równocześnie przypisując opiewanym wodzom plemion beduińskich, ale nie tylko im, właśnie te przymioty w poezji i w Ayyām $a l-{ }^{c} A r a b$. W pierwszych latach islamu pojęcie to zyskało nowe wartości, powiązane przede wszystkim z ideami wniesionymi przez islam. Równocześnie zaczęto kształtować nowy wzorzec, oparty na tradycjach rodzimych, ale nade wszystko na wzorcach wypracowanych na terenach podbitych przez Arabów. Do kultury politycznej kalifatu zaczęła przenikać myśl przedstawicieli narodów podbitych w postaci przekładów i przeróbek dzieł przeznaczonych dla władców. Już w czasie panowania Umajjadów na dworze znalazły się tzw. listy Arystotelesa do Aleksandra ${ }^{1}$, które zapoczątkowały jeden $\mathrm{z}$ bogatszych typów średniowiecznej literatury dydaktycznej - podręczniki dla władcy, zwierciadła dla władcy. Drugim

1 M. Maróth, Correspondence between Aristotle and Alexander the Great: The Earliest Piece of the Adab-Literature [w:] Proceedings of the 20th Congress of the Union Européenne des Arabisants et Islamisants: Budapest, 10-17 September, t. I, Linguistics, Literature, History, The Arabist, ed. K. Dévényi, Budapest 2002, (24-25), s. 103-107; idem, The Correspondence between Aristotle and Alexander the Great. An Anonymous Greek Novel in Letters in Arabic Translation, „Acta Antiqua Scientiarum Hungaricae" 2005, 45, s. 237. Na marginesie warto wspomnieć o polskim wkładzie do badań nad korespondencją Arystotelesa i Aleksandra - badania nad znalezionymi w Stambule arabskimi tekstami zawierającymi listy filozofa do władcy prowadził Józef Bielawski (por. J. Bielawski, Lettre d'Aristote à Alexandre le Grand, „Rocznik Orientalistyczny” 1964, 28; J. Bielawski, M. Plezia, Lettre d'Aristote à Alexandre sur la politique envers les cités, Wrocław-Warszawa-Kraków 1970). 
impulsem piśmiennictwa tego typu była literatura perska, wzbogacona uprzednio wpływami indyjskimi. Wpływy te przyczyniły się do powstania najbardziej fascynującego i bogato reprezentowanego gatunku średniowiecznej prozy arabskiej - literatury adabowej.

Wachlarz podejmowanych problemów w dziełach adabowych był niezwykle obszerny, różnorodne były również formy samych prac: od monografii poprzez antologię na encyklopedii kończąc. Jednym z podstawowych zagadnień w nich omawianych, szczególnie w encyklopediach, było właśnie nakreślenie modelu idealnego władcy muzułmańskiego, jego kompetencji i właściwych zachowań.

Dziełem, o którym można powiedzieć, że zawiera jeden z pierwszych arabskich podręczników dla władcy, jest Al-ciqd al-farìd (Naszyjnikjedyny) ${ }^{2}$ - encyklopedia adabowa, która powstała w Andaluzji w X wieku. Jej szczególna wartość, biorąc pod uwagę tylko nakreślony w niej model władcy, polega na tym, że powstała z dala od centrum, w którym był on kształtowany, chociaż została całkowicie oparta na wzorcach i źródłach wykorzystywanych na Wschodzie. Została napisana nie tylko z pewnego dystansu przestrzennego, ale przede wszystkim czasowego od momentu pojawienia się w centrum kalifatu pierwszych i kolejnych zwierciadeł oraz podręczników dla władcy, przekładanych i wzbogacanych o rodzime wartości wynikające z tradycji oraz nakazów wiary. A biorąc pod uwagę związki jej autora, Ibn 'Abd Rabbiha, z dynastią panującą, była komponowana na dworze i dla dworu. O tym, jak bardzo cała praca, nie tylko jej część poświęcona modelowi władcy, wykorzystuje źródła wschodnie, niech świadczy reakcja bujjidzkiego wezyra aṣ-Ṣāhiba ibn ${ }^{\mathrm{c} A b b a ̄ d a, ~ k t o ́ r y ~ p o ~ z a p o z n a n i u ~ s i e ̨ ~ z ~ k s i e ̨ g a ̨ ~ w y r a z i ł ~ s w o j e ~}$ rozczarowanie, iż nie ma tam nic z twórczości andaluzyjskiej, i stwierdził, że „jest to nasz dorobek ponownie do nas przewieziony"3. Ta pozornie niepochlebna opinia oddaje jednak kwintesencję tworzenia dzieła adabowego, składającego się z cytatów, o którego przesłaniu, nowatorstwie czy przewodnich myślach świadczy sekwencja ich ułożenia w dziele. Ibn ${ }^{\mathrm{c}} \mathrm{Abd}$ Rabbihł jest w tym przypadku typowym reprezentantem sztuki adabowej, a część poświęcona władcy stanowi podsumowanie modelu ukształtowanego na Wschodzie. Z drugiej strony dzieło Ibn 'Abd Rabbiha jest ostatnim, biorąc pod uwagę jego rozmiar, tekstem, stanowiącym swojego rodzaju podsumowanie osiągnięć literatury arabskiej powstającej w centrum kalifatu w Andaluzji. Pod koniec X wieku ustąpiła ona miejsca nowej, powstającej w wyniku wspólnych działań reprezentantów wszystkich nacji tego zakątka, literaturze andaluzyjskiej, odwołującej się do tradycji rodzimych ${ }^{4}$, nieodżegnujących się jednak od tradycji Wschodu.

2 W polskiej literaturze tytuł ten przekładany jest dosłownie jako Naszyjnik jedyny (por. J. Bielawski, Klasyczna literatura arabska, Warszawa 1995, s. 80, 200, 204-209), a także jako Niezwykty naszyjnik. Taką formę stosuje np. Marek Dziekan w przekładzie fragmentów dzieła (por. Ibn 'Abd Rabbihi, Niezwykty naszyjnik, przeł. M.M. Dziekan, wstęp J. Danecki, ,Studia Arabistyczne i Islamistyczne" 1996, 4, s. 171-186).

3 Yāqūt al-Ḥamawī, Mu č̆am al-udabā'=Iršād al-arīb ilā macrifat al-ad̄̄b, ed. I. 'Abbās, Bayrūt 1993, t. II, s. 464. Wszystkie zawarte w artykule tłumaczenia z arabskiego są przekładem autorki - B.O.

4 Wybitny znawca kultury i literatury arabskiej w Andaluzji, Évariste- Lévi-Provençal, określa ją jako hispanoarabską (por. É. Lévi-Provençal, Cywilizacja arabska w Hiszpanii, Warszawa 2006, 
Podstawę niniejszych rozważań stanowić będzie jedynie pierwsza księga dzieła. Jest ona przykładem literatury parenetycznej, kreślącej określone wzorce postępowania ze względu na piastowane stanowiska. Kształtuje typowy dla tego piśmiennictwa model władcy. Można ją uznać za jedno z pierwszych arabskich zwierciadeł dla panującego.

Podkreślić jednak należy, że - jak zaznacza, za Gustavem Richterem, Isabel Toral-Niehoff - pewne aspekty związane ze sprawowaniem władzy zawarte są jeszcze przynajmniej w pięciu księgach ${ }^{5}$. Są to księgi: II - Księga perty unikatowej - o wojnach (Kitāb al-farīda fi-l-hurūb), IV - Księga srebrnego korali$k a$ - o poselstwach (Kitāb al-ğumāna fi-l-wufüd), V - Księga koralu - o tym, jak oficjalnie zwracać się do władców (Kitāb al-marğāna fì muhātaba al-mulūk), XII - Księga zewnętrznego klejnotu - o odpowiedziach (Kitāb al-muğanniba fi-l-ağwiba) oraz XIV - Księga drugiego zewnętrznego klejnotu - o podpisach, wydzialach, dostojnikach $z$ anegdotami o sekretarzach (Kitāb al-muğanniba atțāniyya fi-t-tawqī āt wa-l-fușūl, wa-ș-ṣudūr wa-ahbār al-kataba). Jak sugerują tytuły poszczególnych ksiąg, zawarte w nich treści są jedynie uzupełnieniem wzorca władcy omówionego w księdze pierwszej. Dotyczy to w głównej mierze dwóch ostatnich z wymienionych powyżej ksiąg, w których nauk kierowanych bezpośrednio do rządzących nie jest wiele. Niewątpliwie ciekawy dodatek do stworzenia pełnego paradygmatu dla rządzącego stanowią anegdoty i interesujące opowiastki z historii dynastii muzułmańskich oraz wybranych kalifów, włączone do odrębnej księgi XV - Księgi drugiego złotego koralika - o kalifach, ich historiach i ich bitwach (Kitāb al-'as ăada fil-l-hulafā' 'wa-tawārīhihum wa-ayyāmihum).

\section{Wykorzystane źródła}

Ibn 'Abd Rabbih, rysując wzorzec modelowego władcy, sięgnął do takich samych źródeł, jakie znane były na Wschodzie, i spośród nich wybrał, jego zdaniem, te, które złożyły się na obraz władcy doskonałego. W tym miejscu warto podkreślić to, co dostrzegł w dziele Ibn ${ }^{\mathrm{C}} \mathrm{Abd}$ Rabbiha Walter Werkmeister, badający właśnie

s. 37-69), tutaj proponowane jest jednak pojemniejsze określenie - andaluzyjska, ponieważ odwołuje się do geografii, dzięki temu nie ogranicza ujawnienia udziału w niej reprezentantów wszystkich nacji, które ją tworzyły.

5 I. Toral-Niehoff, The „Book of the Pearl on the Ruler” in the Unique Necklace by Ibn 'Abd Rabbih [w:] Preliminary Remarks, Global Medieval: Mirrors of Princes Reconsidered, eds. N. Yavari, R. Forster, Cambridge 2016, s. 141.

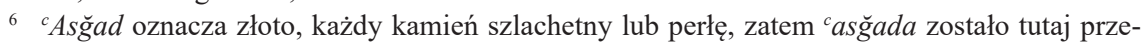
łożone jako koralik ze złota. W tym miejscu należy zwrócić również uwagę na błąd w powszechnie używanej, także na potrzeby niniejszego artykułu, edycji Al-'Iqd al-farìd, w której w przedmowie do dzieła, gdzie podano tytuły poszczególnych ksiąg pracy (chodzi o księgi XI i XV), termin ten został błędnie zapisany jako al-masğada (por. Ibn 'Abd Rabbih, Al-c Iqd al-farìd, ed. M.M. Qamīḥa, Bayrūt 1997, t. I, s. 7), natomiast w tekście, w tytułach odnośnych rozdziałów podano prawidłową formę (por. ibid., t. IV, s. 3 oraz t. V, s. 3). W pełni poprawnie został zapisany np. w starszej edycji (por. Ibn 'Abd Rabbih, Al-c Iqd al-farīd, ed. M.S. al-'Aryān, al-Qāhira 1953, t. I, s. 4, t. IV, s. 2, t. V, s. 2). Ofiarą tego błędu padła cytowana tutaj Toral-Niehoff, podając w transkrypcji tytuły rozdziałów dzieła (por. I. Toral-Niehoff, op. cit., s. 138). 
źródła $A l-c I q d$, który zauważył, że większość z nich, szczególnie materiał anegdotyczny i przeważającą liczbę tradycji, podano anonimowo. Dalsze studia porównawcze doprowadziły go do wniosku, iż zawartość dzieła bazuje w przeważającej mierze na przekazach ustnych, a nie tekstach spisanych ${ }^{7}$. Trudno również nie dostrzec, że dziełem, które zapewne posłużyło Ibn ${ }^{\mathrm{c}} \mathrm{Abd}$ Rabbihowi za wzorzec, zarówno pod względem zawartości treściowej, jak i układu całości, było ${ }^{c}$ Uyūn al-ahbār Ibn Qutayby. Aczkolwiek ponownie, z czym trudno się nie zgodzić, Werkmeister sugeruje, że praca Ibn Qutayby nie była znana Ibn ${ }^{\mathrm{c}} \mathrm{Abd}$ Rabbihowi w wersji spisanej ${ }^{8}$, jedynie z przekazów ustnych.

Dobór źródeł w części poświęconej władcy jest bardzo różnorodny. Podstawową linię podziału można przeprowadzić między źródłami arabskimi a obcymi.

$\mathrm{Na}$ źródła arabskie składają się cytaty z Koranu, tradycje Proroka, ahbār, amțāl (rozumiane tutaj zarówno jako przysłowia, jak i przypowieści), posłanie al-Ḥasana al-Bașrīego, dwa posłania 'Umara ibn al-Hatțāba oraz stosunkowo nieliczne cytaty z poezji, wśród nich, co rzadkie tutaj, trzy krótkie fragmenty utworów samego Ibn 'A Abd Rabbiha9. Znaczna większość anegdot dotyczy okresu wczesnomuzułmańskiego, panowania kalifów prawowiernych, okresu umajjadzkiego, mniej czasów abbasydzkich oraz, być może, nieliczne anegdoty pochodzą z okresu ğāhiliyyi, jedną można z całą pewnością odnieść do tego czasu. Natomiast pozostałe przekazywane są przez bliżej nieprzedstawianych beduinów i trudno je zaklasyfikować pod względem czasu, do którego się odnoszą.

Drugi typ źródeł stanowi materiał niearabski, a przynajmniej tak przedstawiany. Najliczniejszą grupę tworzą źródła perskie i indyjskie - te ostatnie przefiltrowane przez kulturę perską. Są nieliczne źródła pseudogreckie, nawiązujące do popularnej na Bliskim Wschodzie korespondencji Arystotelesa do Aleksandra, pośrednie źródła żydowskie oraz kilka nawiązań do źródeł chrześcijańskich, w tym jedna interesująca - o abisyńskim negusie. Wszystkie podano w postaci małych form literackich.

\section{Układ materiału}

Materiał w dziełach adabowych, szczególnie encyklopediach, układany jest według niepisanych, ale na ogół przestrzeganych reguł. Dotyczą one zarówno rozmieszczenia materiału w całym dziele, jak i w poszczególnych jego jednostkach. Na początku prezentowane są zagadnienia ważne i poważne, a pod koniec mniej istotne i niekiedy zabawne. Ibn ${ }^{\mathrm{c}} \mathrm{Abd}$ Rabbih, układając $A$ - $^{\mathrm{c}} \mathrm{I} q d$, kierował się właśnie tymi zasadami, można zatem założyć, że na początku rozdziału poświęconego władcy omawia najbardziej istotne według niego problemy, a te o mniej-

\footnotetext{
7 W. Werkmeister, Quellenuntersuchungen zum "Kitāb al-ciqd al-farīd" des Andalusiers Ibn 'Abdrrabih (246/860-328/940): Ein Beitrag zur Arabischen Literaturgeschichte, Berlin 1983, s. 463-469.

8 Ibid.

9 Ibn cAbd Rabbih, Al-c Iqd al-farīd, ed. M.M. Qamīḥa, t. I, s. 38, 62, 71. W dalszej części artykułu będzie wykorzystywana tylko ta edycja dzieła.
} 
szej wadze pozostawia na koniec. Zatem kolejność przedstawianych problemów jest proporcjonalna do ich rangi.

Całe dzieło składa się z krótkiego wstępu i dwudziestu pięciu ksiąg różnej długości, których tytuły pochodzą na ogół od nazw kamieni szlachetnych. Środkowa księga - trzynasta - nosi tytuł Księga kamienia centralnego o oracjach. Następujące po niej dwanaście kolejnych stanowi pod względem nadanych im tytułów lustrzane odbicie pierwszych dwunastu. Mianowicie - gdy pierwsza nosi tytuł Ksiegga perly - o władzy, to ostatnia, dwudziesta piąta, zatytułowana jest Ksiega drugiej perly petna ciekawostek, upominków, dykteryjek i żartów, a gdy np. piąta to Ksiegga koralu - o tym jak oficjalnie zwracać się do władców, to dwudziesta pierwsza nosi tytuł Ksiega drugiego koralu o kobietach i ich przymiotach.

Będąca przedmiotem niniejszych rozważań Księga perty - o władzy (Kitāb al-lu'lu'a fi-s-sultāan) składa się z krótkiego wstępu i dwudziestu rozdziałów nierównej długości i zawartości. Tytuły poszczególnych rozdziałów w bezpośredni i jasny sposób informują potencjalnego adepta sztuki rządzenia, o czym będzie w nich mowa. Ich zawartość budują samodzielne jednostki tekstowe - małe formy literackie, takie jak anegdoty $(a h b \bar{a} r)$, przysłowia i przypowieści (amt $\bar{a} l)$, tradycje

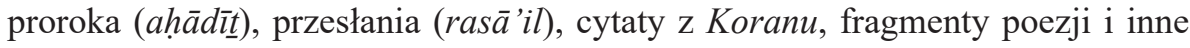
drobne formy. Jedynym czynnikiem łączącym poszczególne jednostki w obrębie rozdziału jest konwergencja tematyczna, co jest zjawiskiem charakterystycznym dla literatury adabowej.

\section{Przekaz}

\section{Wstęp}

Określając władcę, Ibn 'Abd Rabbih stosuje synonimicznie trzy terminy: sulțān, imām, malik. O ile pojęcia sulțān i malik stosowane są powszechnie w odniesieniu do kompetencji rządzącego, o tyle termin imām jest w tym kontekście stosowany znacznie rzadziej. Posługuje się nim niekiedy Ibn al-Muqaffa ${ }^{\mathrm{c}}$ w swoim Risālāt fi-ș-ṣahăba, jednak najczęściej kierując się bezpośrednio do odbiorcy - władcy, stosuje zwrot Amìr al-mu'minin (Władca wiernych). Podobnie Ibn Qutayba $\mathrm{w}^{c} U y \bar{u} n$ al-aḩbār niekiedy określa rządzącego mianem imām. Ibn ${ }^{\mathrm{c}} \mathrm{Abd}$ Rabbih korzystał pośrednio z obu tych dzieł i może to być właśnie ich wpływ.

Na samym początku wstępu do księgi wypowiada się bezpośrednio autor i nie skrywając się za tekstem cytowanym, definiuje, czym jest według niego władza. Rozumie ją jako trzymanie za wodze wszystkich spraw (zimām al-umūr), porządkowanie praw (niżām al-huqūq) oraz określanie prawnych konsekwencji ich przekraczania. Władca jest w centrum spraw świeckich oraz wiary i dlatego cieszy się opieką Boga, roztoczoną nad jego królestwem i nad poddanymi. Dzięki tej opiece jego bliscy są bezpieczni, ciemiężeni doznają sprawiedliwości, a ciemiężcy nie unikną kary, ci zaś, którzy czują zagrożenie, zyskają gwarancję bezpieczeństwa ${ }^{10}$. Ten jakże zwarty opis wskazuje jednak na dwa najważniejsze

\footnotetext{
10 Ibid., t. I, s. 9.
} 
elementy władzy: zależność od boskiej opieki oraz stanie na straży przestrzegania prawa, co skutkować będzie sprawiedliwymi rządami. W dalszym ciągu wstępu i w następujących po nim rozdziałach zakres działania tych dwóch czynników determinujących władzę jest obszernie omówiony.

Mianowicie ścisłe powiązania władzy z Bogiem dobitniej podkreślają stwierdzenia podane na podstawie tekstu cytowanego. Według jednego z przekazów, przytoczonego na mocy autorytetu Wahba ibn Munabbiha ${ }^{11}$, Bóg miał zwrócić się do proroka Dawida następującymi słowami:

Zaprawdę jestem Bogiem, królem królów i serca królów są w moim ręku. Tym, którzy będą mi posłuszni, ześlę władców miłosiernych, tym, którzy mnie nie usłuchają, ześlę władców mściwych $^{12}$.

Odwołanie się w tym miejscu do postaci proroka i króla Dawida ma istotne znaczenie, bo to właśnie jemu, w świetle Koranu, bezpośrednio sam Bóg miał powierzyć sprawowanie władzy w swoim zastępstwie, nazywając go kalifem (halīfa), oraz przekazać rozsądzanie sporów na ziemi ${ }^{13}$. Historia Dawida, zawarta $\mathrm{w}$ Koranie i w hadisach, została wzbogacona w opowieściach inspirowanych Koranem o elementy, które przeniknęły głównie z tradycji żydowskiej ${ }^{14}$. Tak powstały materiał przyczynił się do zbudowania w kulturze islamu wizerunku Dawida jako wzorca władcy sprawiedliwego. Podany wyżej cytat wskazuje dodatkowo na charakter relacji Bóg-władca-poddani, uzależniając od postawy tych ostatnich jakość danego im zwierzchnika.

Do podstawowych zadań władcy, w świetle dalszego wywodu, należy dbałość o interes poddanych oraz dobrobyt tych ludzi, którzy są mu posłuszni. Wynika z tego, że szczególną troską rządzącego otoczeni będą przede wszystkim ci, którzy są powolni władzy.

Cechą podstawową władcy, która wydaje się zasadnicza dla wszystkich jego działań, jest sprawiedliwość, jej znaczenie zostało poparte słowami Muhammada. Miał on stwierdzić, iż ten, kto jest przez godzinę sprawiedliwy, działa lepiej, niżby modlił się przez sześćdziesiąt lat ${ }^{15}$. Przy czym sprawiedliwość władcy ma zadowolić większość, jest bowiem zjawiskiem naturalnym, że nie wszyscy będą usatysfakcjonowani, a władca nie jest w stanie zabezpieczyć się przed niezadowoleniem części poddanych. Powinien to niezadowolenie tolerować tak długo, dopóki nie przerodzi się ono w czyny wymierzone przeciwko niemu. W świecie

11 Wahbowi ibn Munabbihowi, jednemu z najstarszych zbieraczy tradycji o prorokach, przypisywane jest autorstwo Historii Dawida (Hadīt Dāwiud). Wersję spisaną tej historii zachowuje rękopis datowany na rok 844, przechowywany w Heidelbergu (PSR Heid Arab 23). Praca ta została wydana i przełożona na język niemiecki (por. R.G. Khoury, Wahb b. Munabbih. Der Heidelberger Papyrus PSR Heid Arab 23 [Codices Arabici Antiqui], Wiesbaden 1972), ale nie zawiera przytoczonego powyżej zdania, mogło ono pochodzić z innych przekazów, należy pamiętać, że Ibn ${ }^{\mathrm{c} A b d}$ Rabbih posiłkował się przede wszystkim źródłami ustnymi.

12 Ibn 'Abd Rabbih, op. cit., t. I, s. 9.

13 Koran, 38:26 - yā Dāwūd innā ğa $\ln \bar{a}$-ka halīfat ${ }^{a n}$ fi-l-arḍ fa-ahkum bayna an-nās bi-l-haqqO Dawidzie, uczyniliśmy cię następcą (kalifem) na ziemi, rozsądzaj więc ludzi według prawdy.

14 F. Mojtabā'1, Dāwūd [w:] Encyclopaedia Iranica, New York 1994, t. VII, s. 161.

15 Ibn ${ }^{\mathrm{c}}$ Abd Rabbih, op. cit., t. I, s. 10. 
islamu jest to nad wyraz rzadko uświadamiane rządzącym zagrożenie. Władca, któremu Bóg powierzył władzę, ma wypełniać obowiązki religijne i dbać o dobro swoich poddanych. Według Ibn 'Abd Rabbiha wiara, władca i poddani stanowią harmonijną, hierarchiczną, nierozerwalną i komplementarną całość. Tę zależność przedstawia, posiłkując się słowami Ka'ba al-Aḥbāra ${ }^{16}$ :

Islam, władca i lud są jak namiot, podpora i kołki. Islam to namiot, podporą jest władca, a kołkami lud, żadne z nich nie obędzie się bez pozostałych ${ }^{17}$.

Zamieszczone we wstępie uwagi autora oraz cytaty pozwalają na wyciągnięcie wniosku, że Bóg, w pewnym sensie, daje poddanym takiego władcę, na jakiego zasługują. Władza zatem pochodzi od Boga, poddani nie mają żadnego wpływu na to, kto będzie władcą, ale swoją postawą mogą wpłynąć na to, jaki będzie ów władca. Następujące po wstępie rozdziały uzupełniają jednak tę relację $\mathrm{o}$ analogiczny mechanizm działania $\mathrm{w}$ stronę przeciwną; to znaczy postawa i zachowanie, a przede wszystkim uczciwość poddanych jest odbiciem zachowań władcy. Warto też zwrócić uwagę, że wykorzystane we wstępie autorytety to przedstawiciele najstarszego pokolenia, żyjącego w czasie rodzenia się i rozwoju islamu. Obydwaj cytowani - Wahb ibn Munabbih i Kacb al-Aḥbār - działali w Jemenie, gdzie wyraźnie zaznaczyły się wpływy judejskie.

\section{Rozdziały}

Każdy z następujących po wstępie dwudziestu rozdziałów teoretycznie poświęcony jest jednemu zagadnieniu, dotyczącemu różnych aspektów sprawowania władzy, pożądanych cech władcy, jego kompetencji oraz umiejętności doboru funkcjonariuszy państwowych i współpracy z otoczeniem. De facto - niektóre zalecane władcy postawy i cechy są powielane, a przesłanie zawarte w kilku rozdziałach bardziej definiuje kompetencje najbliższych współpracowników władcy niż jego samego. Ponieważ, jak wspomniano, sekwencja omawianych problemów wskazuje na wagę, jaką autor nadaje poszczególnym zagadnieniom, najpierw warto przedstawić kolejność omawianych problemów. Otóż pierwsze dwa rozdziały adresowane są głównie do doradców i współpracowników, zalecane jest $\mathrm{w}$ nich posłuszeństwo i umiejętne postępowanie $\mathrm{z}$ władcą. $\mathrm{W}$ trzecim rozdziale poruszane są zagadnienia dotyczące zarówno władcy, jak i jego bliskich współpracowników. W kolejnych czterech, kierowanych wyłącznie do rządzącego, omawiane są kwestie doboru współpracowników, na co zwracać uwagę przy obsadzaniu stanowisk, jak karać i jak nagradzać urzędników, poruszono także zagadnienie sprawiedliwego postępowania i dbałości o dobro poddanych. Następ-

$16 \mathrm{Ka}^{\mathrm{c} b}$ ibn Aḥbār - jemeński Żyd, który w czasie panowania kalifa prawowiernego ${ }^{\mathrm{C} U m a r a}$ ibn al-Hुațāāba przeszedł na islam, jego słowa stanowią jedno z najstarszych źródeł wczesnych przekazów muzułmańskich zabarwionych tradycjami żydowskimi. Niektóre średniowieczne źródła zarzucają mu judaizację islamu (por. M. Schmitz, Kacb al-Aḥbār [w:] The Encyclopaedia of Islam, Leiden 1997, t. IV, s. 317).

${ }^{17}$ Ibn ${ }^{\mathrm{c} A b d}$ Rabbih, op. cit, t. I, s. 11. 
ny - siódmy - rozdział przeznaczony jest zarówno dla władcy, jak i doradcy. Skupia się na prezentacji relacji między władzą, urzędnikami i poddanymi, pokazuje, że postawa i działanie władcy rzutuje na działania i postawę doradców, co przekłada się na zachowania poddanych. W kolejnych sześciu rozdziałach, kierowanych tylko do władcy, omówione są cechy władcy idealnego, jego postawa wobec otoczenia i poddanych, wybrane zachowania w różnych okolicznościach, z jakimi może spotkać się rządzący, problemy w relacjach ze współpracownikami oraz konieczność umiejętności zachowywania tajemnic. W pozostałych rozdziałach zawarto przekaz dla panującego, ale przede wszystkim dla otoczenia. Dotyczy umiejętności doradzania, powściągliwości w zabieganiu o stanowiska, konieczności wykazywania się lojalnością wobec rządzącego, gotowości na ewentualną dymisję oraz kompetencji i doboru sędziów. Jak widać z tego pobieżnego przeglądu, zarówno porządek, jak i liczba prezentowanych zagadnień wskazują, iż autor Al-cIqd większy nacisk kładł na kompetencje i dobór współpracowników aniżeli na samo kształtowanie panującego. Nie sposób nie zauważyć tu pewnych analogii do Risālat aș-ṣahăāba Ibn al-Muqaffacy, który nakreślił mechanizm władania państwem poprzez zdefiniowanie kompetencji otoczenia króla. $Z$ tą jednak różnicą, że Ibn al-Muqaffa ${ }^{c}$ zwracał się bezpośrednio do władcy, tymczasem zamieszczone przez Ibn ${ }^{\mathrm{A}} \mathrm{Abd}$ Rabbiha pouczenia w postaci anegdot, przypowieści czy mądrości kierowane są również do otoczenia dynasty. Trzeba jednak zaznaczyć, że władca, wczytując się w podane przykłady, dostrzega mechanizmy działań doradców i dworskich urzędników, ich zaplecze oraz rozmaite postawy, co może ułatwić współpracę z nimi, poprawny dobór, zrozumienie ich zachowań, oczekiwań i postępowania.

W obszernym i bogatym tematycznie materiale, zawartym w przedstawianych wyżej rozdziałach księgi pierwszej $A$ - $^{c} I q d$, można wyodrębnić pod względem charakteru podanych zaleceń trzy zasadnicze typy pouczeń: budowanie morale władcy, praktyczne wskazówki dla niego oraz rady dla współpracowników panującego.

\section{Budowanie morale}

Wspaniały władca to taki, który posiada pewien zasób walorów i cnót, gwarantujących jego doskonałą postawę moralną, odpowiadającą powierzonemu mu przez Boga zadaniu. Cnót tych, zasad i przymiotów nie należy mylić z pewnymi praktycznymi umiejętnościami, zachowaniami czy reakcjami na określone sytuacje, te bowiem mają charakter fakultatywny, natomiast zestaw kardynalnych zasad moralnych wydaje się obligatoryjny. Podstawową zasadą, jaką powinien kierować się władca, jest sprawiedliwość. Ta kwestia poruszona została we wstępie, ale Ibn 'Abd Rabbih powraca do niej wielokrotnie w następujących po nim rozdziałach. Jest to cnota obejmująca wiele aspektów postępowania rządzącego, rozumiana jako działanie w zgodzie z prawem, szlachetność, uczciwość, prawość, 
bezstronność ${ }^{18}$. Sprawiedliwość władcy jest gwarancją pomyślności jego władzy. Niesprawiedliwość zarówno w nagradzaniu, jak i karaniu przysparza tylko wrogów, co obrazuje doskonale przytoczona przypowieść:

Dwóch ludzi chowało głęboką urazę do władcy: człowiek, który czynił dobrze wraz z innymi, ci zostali nagrodzeni, a jemu odmówiono nagrody, i człowiek, który popełnił zły czyn, tak jak inni, ten został ukarany, tamtym przebaczono. Władca powinien strzec się przed nimi dwoma ${ }^{19}$.

Wskazywanie władcy wagi sprawiedliwego postępowania nierzadko pokazywane jest na przykładach rządzących, którzy nie kierowali się tą zasadą, czy to nieumyślnie, czy z rozmysłem. Podkreślona jest też rola zadośćuczynienia za wyrządzoną niesprawiedliwość. Władca nie tylko powinien być sprawiedliwy, ale musi również domagać się od działających w jego imieniu dostojników sprawiedliwości okazywanej poddanym bezpośrednio podlegającym ich zarządom, ponieważ działają oni w jego imieniu. Jeden z kalifów umajjadzkich, 'Umar ibn 'Abd al-'Azīz, tak miał doradzać swojemu gubernatorowi: „Umocnij swoje miasto sprawiedliwością ( ${ }^{c} a d l$ ) i oczyść jego drogi ze wszelkiej niesprawiedliwości (zulm)" ${ }^{\prime 20}$.

Liczne exempla, pokazujące rozmaite obszary działania sprawiedliwości i wagę kierowania się nią w zarządzaniu państwem, dopełnia opis sprawiedliwego władcy zawarty w posłaniu al-Ḥasana al-Bașrīego, a kierowany do 'Umara ibn 'Abd al-'Azīza, w którym ten wybitny kaznodzieja poucza, co czynić, by być sprawiedliwym i jak traktować poddanych. Według autora przesłania władca sprawiedliwy powinien być dla swojego ludu jak pasterz dla swoich wielbłądów, które prowadzi na najlepsze pastwiska i chroni przed dzikimi zwierzętami, powinien być jak ojciec, który poucza swoje dzieci, pracuje na nie i zabezpiecza na wypadek swojej śmierci, musi być jak matka, czuła i oddana swojemu dziecku, jak ten, który jest opiekunem sierot i strzeże ich majątku ${ }^{21}$. W przesłaniu al-Hasana al-Bașrīego sprawiedliwość władcy ma skutkować nie tylko rządami prawa, ale dbałością także o sprawy poddanych. Opieka i troska o powierzony rządzącemu lud jest właśnie wyrazem jego sprawiedliwego postępowania.

Sprawiedliwy władca, według wskazań al-Ḥasana al-Bașrīego, jest pośrednikiem między Bogiem a poddanymi. To Bóg powierzył mu władzę nad ludem, ma więc wsłuchiwać się w boskie przykazania i przekazywać je poddanym ${ }^{22}$. Głównym motorem postępowania rządzącego ma być świadomość, że Bóg nie tylko dał mu władzę, ale przed Bogiem będzie rozliczany za jej sprawowanie. Ta zasada

18 Problem sprawiedliwości jest zagadnieniem niemal obowiązkowym w przesłaniach kierowanych do władcy, często w celu wzmocnienia jego rangi ,sprawiedliwość” " $a d l$ kontrastowana jest z pojęciem zulm, oznaczającym ,ucisk”, „niegodziwość”, „niesprawiedliwość”. Obszerniej na ten temat por. E. Ohlandr, Enacting Justice, Ensuring Salvation: The Trope of the “Just Ruler” in Some Medieval Islamic Mirrors for Princes, ,The Muslim World” 2009, 99/2, s. 237-239. Ibn “Abd Rabbih zazwyczaj stosuje synonimiczne określenia macdala i mazlima.

19 Ibn 'Abd Rabbih, op. cit, t. I, s. 27.

20 Ibid., s. 30.

21 Ibid., s. 34.

22 Ibid. 
jest o tyle ważna, że znaczna część wstępu koncentruje się właśnie na zależności władzy od Boga i - podobnie jak temat sprawiedliwości - jest przypominana w kolejnych częściach Księgi. Zależność tę obrazują słowa 'Umara ibn 'Abd al'Azīza: „Znając swoją moc nad poddanymi, pamiętaj o mocy Stwórcy nad tobą i wiedz, że dla Boga panujący jest w takiej pozycji jak poddani dla ciebie"23.

W zasadzie tej mieści się również głęboka wiara, pobożność i stosowanie przepisów islamu. Aczkolwiek należy zaznaczyć, że nieliczne tylko z zamieszczonych anegdot, przypowieści czy pouczeń budują bezpośrednio wizerunek władcy jako pobożnego wiernego z oddaniem wypełniającego obowiązki religijne, bowiem, jak można domniemać, pobożność i religijność to wypadkowa faktu bycia muzułmaninem, a sterowanie krajem rozumiane jest jako dodatkowe zadanie.

Kolejne przymioty władcy nie są już tak często i dobitnie podkreślane, ale dopełniają jego wzorzec moralny. Ze sprawiedliwością powiązane jest miłosierdzie i umiejętność przebaczania. Cnotą rządzącego jest skromność, a nawet pokora $\left(\operatorname{taw} \bar{a} d u^{c}\right)$, taka postawa zapewnia mu szacunek poddanych i otoczenia dworskiego. Skromność ma wyrażać się nie tylko w postawie niewywyższania się nad innymi, ale przede wszystkim w rezygnacji z zamiłowania do nadmiernego zbytku. Jako przykład kalifa skromnego i bezkompromisowego w stosunku do siebie i podwładnych wskazywany jest ' Umar ibn al-Huațāab, bohater licznych anegdot. Zalecana jest także rozwaga i namysł, a nie pochopne działanie. Nierzadko zamieszczone pouczenia odnoszą się do więcej niż jednego przymiotu władcy, a dawanie rad nie leży jedynie w kompetencji mędrca czy doradcy:

Al-Manșūr rzekł do swojego syna ${ }^{\mathrm{c} A b d}$ Allāha al-Mahdīego: - Nie podejmuj decyzji, póki dokładnie nie rozważysz sprawy, rozważanie jest bowiem dla mędrca niczym przejrzenie się w lustrze, które ukaże mu dobre i złe strony. Wiedz też, że nic bardziej niż pobożność nie doskonali kalifa, nic też nie czyni władcy lepszym niż posłuszeństwo [Bogu - B.O.], poddanych zaś tylko władcy sprawiedliwość lepszymi uczyni. Ludzie, którzy najbardziej zasługują na przebaczenie, to ci, którzy w pełni świadomi są swojej winy. Najpodlejsi zaś są tacy, którzy niżej stojących w błąd wprowadzają ${ }^{24}$.

Pouczenia i rady artykułowane są także w postaci maksym obejmujących rozliczne aspekty władzy: „Najbardziej rozsądnym (ahzam) z królów jest ten, który przedkłada powagę nad żartem, rozwagę nad emocją, rozwaga jest towarzyszem doskonalącym rezultaty jego czynów, a czyny są wyrazem jego sumienia”25.

Mimo zalecanej powagi niektóre anegdoty wskazują, iż poczucie humoru jest równie ważne, ale należy wiedzieć, z kim się żartuje, a przekraczając granice, umieć załagodzić sytuację. Obrazuje to wymiana zdań, do jakiej miało dojść pomiędzy Mu’āwiyą ibn Ab̄̄ Sufyānem a Hुuraymem an-Nācimem: „Huraym anNācim wszedł do Mưāwiyi ibn Ab̄̄ Sufyāna. Mưāwiya spojrzał na jego nogi i rzekł: Cóż za nogi, jaka szkoda, że nie należą do niewolnicy! Wtedy odpowie-

\footnotetext{
23 Ibid., s. 31.

24 Ibid., s. 39.

25 Ibid., s. 41.
} 
dział mu Huraym: Podobnie jak twój tyłek, Władco Wiernych. Cios za cios - odparł [kalif - B.O.] - lecz ten, co zaczął, jest podlejszy"26.

Bardzo istotną cechą jest opanowanie, powściąganie swoich emocji i niedziałanie pod wpływem gniewu. Jeden z królów tak opisywał politykę swoich rządów: „Nie żartuję, niezależnie, czy obiecuję, czy grożę, kiedy nakazuję lub zabraniam i nie karzę, kiedy jestem w gniewie"27.

Władcy nie przystoi także lekceważące podejście do spraw, które jedna z maksym sytuuje wśród takich niedoskonałości jak despotyzm czy pośpiech: „Trzy rzeczy przysparzają mu [czyli władcy - B.O.] największych szkód: despotyzm (al-istibdād), lekceważenie (at-tahāwun) i pośpiech ( $\left.{ }^{c} a \breve{g} a l a\right){ }^{\prime 28}$.

Powyższe cechy i zasady moralne, jakimi powinien kierować się rządzący i które winien prezentować, składają się na raczej spójny model idealnego władcy, gwarantującego bezpieczny i sprawiedliwy byt swoich poddanych. Najobszerniej i najdobitniej omówiona jest kwestia sprawiedliwości, wszystkie pozostałe pouczenia podane są jako uzupełnienie tego podstawowego atrybutu doskonałego władcy. Materiał wykorzystany do zarysowania sylwetki moralnej idealnego władcy jest w przeważającej mierze pochodzenia arabskiego. Są to anegdoty o kalifach prawowiernych, umajjadzkich czy abbasydzkich, rzadziej bohaterami są władcy sasanidzcy czy abisyńscy. Tworzą go również cytaty z Koranu i nieliczne hadisy.

\section{Praktyczne wskazówki dla władcy}

Praktyczne wskazówki nie składają się na postawę moralną, ale dopełniają wizerunek i wskazują na różne przedsięwzięcia i zachowania, które udoskonalą panowanie. O ile znaczna większość zasad i cech budujących postawę moralną nie miała charakteru opcjonalnego, o tyle tutaj, w niektórych przypadkach, wskazywane jest alternatywne działanie. Te praktyczne wskazówki nie są w księdze wyszczególnione, ale podane łącznie z zalecaniami dotyczącymi postawy moralnej króla.

Najważniejszą ze wskazówek, bo powtarzaną bez względu na to, czy mowa o doradcach, szambelanach, urzędnikach administracji, sędziach, czy innych współpracownikach, jest zasada dobrego, starannego doboru ludzi. Bezdyskusyjnym argumentem za takim postępowaniem jest fakt, że to ci ludzie reprezentują władcę i po ich czynach jest on oceniany przez poddanych, ale i na zewnątrz państwa. Dobór ten mają ułatwić w przypadku niektórych stanowisk wyliczone, oczekiwane kompetencje potencjalnego dostojnika. Praktyczną wskazówką jest również uwaga, aby nie wyznaczać na stanowisko tych, którzy o to usilnie zabiegają. Władca, nominując danego człowieka na wysokie stanowisko, powinien zasięgnąc rady zaufanych towarzyszy. Wyznaczeni w ten sposób przedstawiciele władcy powinni być dobrze wynagradzani za właściwe działanie, aczkolwiek

\footnotetext{
26 Ibid., s. 52.

27 Ibid., s. 23-24.

28 Ibid., s. 59.
} 
wzory pokazujące praktyki stosowane przez 'Umara ibn al-Hatțāba wskazują raczej na daleko idącą oszczędność w wynagradzaniu. Panujący ma prawo oczekiwać od dostojnika dworskiego najlepszego działania, ale powinien wyraźnie określić, jakie obowiązki ma wypełniać nominat. Mianowanym dostojnikom mogą przytrafić się błędne decyzje, w takim przypadku panujący może wybaczyć błędy, ale nie wtedy, kiedy stają się zasadą. W przypadku karania za popełnione wykroczenia zalecane jest posiłkowanie się cnotami moralnymi: miłosierdziem i rozwagą - należy karać z rozwagą i przebaczać z miłosierdziem. Nie należy także zwlekać z nagradzaniem, ale też innych spraw nie wolno odwlekać na później. Karać należy adekwatnie do winy, kierując się wskazaniem przypisywanym Mucāwiyi: „Powiedział Mu’āwiya: Nie używam miecza, kiedy starczy bat, ani bata, kiedy starcza język. A kiedy łączy mnie z ludem zaledwie włos, nie przecinam go" 29 .

Obowiązkiem władcy jest troska o dobro poddanych, nie ze względu na dbałość o ich los, ale głównie dlatego, że państwo to rodzaj naczyń połączonych: bezpieczeństwo i pomyślność poddanych idzie w parze z bezpieczeństwem i pomyślnością władcy.

Ciekawe obrazy, z punktu widzenia relacji panującego z poddanymi, zawiera część poświęcona sprzeciwowi w stosunku do władcy i jego nań reakcji. Składa się z wielu anegdot pokazujących uzasadniony, a niekiedy zuchwały sprzeciw względem władcy, graniczący z całkiem niestosownym zachowaniem. Reakcja bohaterów anegdot, kalifów, jest bardzo różna - od srogiej kary do nieuzasadnionej pobłażliwości. Nie ma tu wskazania na konkretne działanie, ale na wachlarz możliwych konsekwencji, co doskonale obrazuje alternatywność w zastosowaniu praktycznych wskazówek. Uzupełnieniem tej części jest kolejna o podobnym przesłaniu, sprzeciwie wobec władcy, ale wyrażonym przez ludzi wiary ( $\mathrm{ahl} \mathrm{ad-}$ dinn). W tym przypadku zaleca się władcy szczególną wyrozumiałość i cierpliwe wsłuchanie się w, być może, uzasadniony opór.

Istotną rolę odgrywa dobra współpraca z dostojnikami na dworze, szczególnie tymi, na których barkach spoczywa doradzanie panującemu. Powinien on nie tylko umieć wybrać sobie doradców, ale też umiejętnie korzystać z ich rad. Zadanie takiego doradcy zakłada niekiedy posiadanie niemal makiawelicznych umiejętności, kiedy przestrzegany jest przed tym, by nie dawać władcy takich rad, jakich nie chciałby usłyszeć. $Z$ uwagi na to, że jest to przesłanie zamieszczone w części kierowanej do panującego, może też być odczytane jako przestroga dla króla, który ma poznać mechanizmy działania współpracowników. W doborze doradców należy kierować się zasadą archetypicznego wizerunku šayha, mędrca, zawierającą się w sekwencji: „wiek równa się doświadczenie, a to przekłada się na mądrość”. Panujący nie tylko mianuje na stanowiska, ale także zwalnia dostojników z urzędu, dlatego wśród praktycznych rad są także i te poświęcone przykładom taktownego lub drastycznego odwoływania ze stanowisk. Tutaj również pokazany jest cały wachlarz zachowań.

29 Ibid., s. 25. 
Umiejętnością konieczną dla władcy jest zdolność zachowywania tajemnic dla siebie, niepowierzania ich pochopnie innym, jeżeli konieczne jest podzielenie się tajemnicą, to najlepiej zrobić to w gronie jak najmniejszej liczby osób. Sztuka utrzymywania tajemnic jest darem zalecanym nie tylko sprawującym rządy, jest również jednym ze stałych zagadnień encyklopedii adabowych. W zakresie kompetencji najbliższego otoczenia rządzącego leży dyskretne przypominanie mu o obowiązku dotrzymywania danego słowa, w kontekście analizowanego tekstu można je uznać za niebezpośrednią wskazówkę dla adresata tej części $\mathrm{Al} l^{c} \mathrm{I} I q d$.

\section{Rady dla współpracowników}

Zagadnienie to zostało tu już częściowo omówione w partii poświęconej praktycznym wskazówkom dla władcy. Jedynie pobocznie wiąże się ono z kształtowaniem jego modelu, poprzez przedstawienie mechanizmów i zaplecza działania dostojników dworskich, wyższych urzędników państwowych czy sędziów, których poznanie może być dla panującego owocne, dlatego zasadne wydaje się jedynie pobieżne przedstawienie najważniejszych problemów.

Najistotniejszą cechą dostojnika dworskiego jest jego lojalność. Współpracownikom władcy zaleca się bezwzględne posłuszeństwo, ale też subtelność w postępowaniu z panującym. Taktyka ta polega również na schlebianiu władcy, który poznając ją, powinien być uodporniony na wszelkie próby przypodobania się mu. Niestosowne jest dopominanie się o stanowisko, zabieganie o urzędy, może to wywołać reakcję odwrotną. Od sędziów oczekuje się wysokich kompetencji i uczciwości, bo to oni bezpośrednio działają wśród ludu w imieniu Boga i władcy.

Zaproponowany przez Ibn 'Abd Rabbiha profil władcy jest nie tylko spójnym, ale - zgodnie z tradycjami literatury typu zwierciadło dla władcy - wyidealizowanym modelem, którego celem jest wskazanie wzorca, do którego winien jedynie zbliżyć się dynasta. Jest to też model władcy na czas pokoju, nie ma w Księdze zagadnień dotyczących relacji z przywódcami wojsk ani z armią, nie zaleca się rządzącemu odwagi, męstwa, nieugiętości w ściganiu wroga, przebiegłości ani żadnej taktyki wojennej. Mimo iż odwołuje się także do źródeł wczesnoarabskich, nie przystaje do ideału męża, wojownika czy przywódcy plemiennego (sayyida), a więc też rządzącego, który był kultywowany w okresie przedmuzułmańskim, kiedy ideałem był etos stanowiony przez wartości zawarte w kodeksie murū'a, a najważniejszymi cnotami były waleczność, odwaga, poczucie honoru, hojność i gościnność. Prawdą jest, że wartości te nie dotyczyły tylko wodza, ale także wodza. Ten nowy model, przedstawiony w dziele Ibn 'Abd Rabbiha, jest wynikiem rewolucji, jaka nastąpiła w społeczeństwie, na którą złożyły się nowe warunki życia, głównie zmiana trybu z koczowniczego na osiadły, nowa wiara, pozyskanie nowych terenów i, przede wszystkim, znaczny wpływ tradycji kulturowych przedstawicieli narodów podbitych. Tradycyjny beduiński ideał władcy zachowany został w poezji, w której nadal podkreślane są takie wartości jak odwaga, szczodrość, poczucie honoru, czasem waleczność. Taki model władcy wy- 
daje się komplementarny wobec wzorca stworzonego w typowych zwierciadłach, aczkolwiek nie można wykluczać swojego rodzaju dychotomii.

Ibn 'Abd Rabbih kreuje model doskonałego władcy, w pełni posiłkując się tymi samymi źródłami, które wykorzystywali twórcy zwierciadeł dla władcy działający na Wschodzie. Biorąc za przykład Księgę władcy z ${ }^{c} U y \bar{u} n$ al-ahbār Ibn Qutayby, podobnie jak ten $a d \bar{i} b$ ze Wschodu, kształtuje nowy arabski model literatury budującej dla rządzącego. Sprowadzony do kalifatu przez Ibn al-Muqaffacę paradygmat perski obejmował również zagadnienia dotyczące organizacji i administrowania państwem. Wzorując się na przełożonym przez siebie Przesłaniu Tansara $^{30}$, Ibn al-Muqaffa ${ }^{\mathrm{c}} \mathrm{W}$ swoim Risālat aș-ṣaḥāba wprowadził do organizacji państwa zislamizowany model kręgu sprawiedliwości, zakładający zarząd i nadzór kalifa nad poszczególnymi grupami społecznymi i funkcyjnymi ${ }^{31}$. Wskazał też błędy poprzedniej dynastii i kierunki, w jakich powinna pójść reorganizacja kraju. Ibn 'Abd Rabbih i Ibn Qutayba ograniczają się do samego podania obrazu idealnego władcy, dobrze współpracującego z najbliższym otoczeniem. Taka postawa była zapewne wynikiem bardziej stabilnej sytuacji politycznej w porównaniu z czasami autora Risālat aṣ-ṣaḥāba.

$\mathrm{Z}$ tego wizerunku wyłania się jeszcze jeden wniosek; mianowicie ideał władcy muzułmańskiego jest niemal tożsamy z podstawowymi atrybutami archetypicznego ideału władcy średniowiecznego, któremu władza została nadana przez Boga, który miał bronić swojej wiary, być ojcem dla swoich poddanych i rządzić sprawiedliwie. Jedynie mądrość, podkreślana w średniowiecznych europejskich tekstach, u Ibn ${ }^{\mathrm{c}} \mathrm{Abd}$ Rabbiha jest nieco mniej akcentowana ${ }^{32}$.

30 Tansar, zoroastryjski kapłan i doradca perskiego władcy Ardašira I z dynastii Arsacydów, jest autorem przesłania do jednego z wasali króla. Tekst przesłania został zmodyfikowany w czasach panowania Sasanidów, a jego ostrze wymierzone w poprzednią dynastię Arsacydów. Ibn al-Muqaffa ${ }^{\mathrm{c}}$ przełożył dzieło na arabski, a przekład stał się podstawą innych przekładów, m.in. na perski. Przekład współczesny angielski - por. The Letter of Tansar, przeł. M. Boyce, Roma 1968.

31 J.A. London, The Abbasid "Circle of Justice": Re-reading Ibn al-Muqaffac's Letter of Companionship [w:] Comparative Political Theory in Time and Place, eds. D.J. Kapust, H.M. Kinsella, New York 2017, s. 34-35.

32 Dodatkowym fenomenem i dowodem na uniwersalność - tym razem formy podania nauk - jest sam gatunek zwierciadła dla władcy, literatury obecnej na Wschodzie i Zachodzie zarówno w czasach antyku, chociaż wtedy określanej inaczej, jak i w średniowieczu. Prowadzone są badania nad ewentualną wspólnotą formy oraz możliwych wzajemnych powiązań - por. L.T. Darling, Mirror for Princes in Europe and the Middle East: A Case of Historiographical Incommensurability [w:] East Meets West in the Middle Ages and Early Modern Times: Transcultural Experiences in the Premodern World, ed. A. Classen, Berlin-Boston 2013; M. Haake, Writing to a Ruler, Speeking to the Ruler, Negotiating the Figure of Ruler: Thoughts on "Monocratological” Texts and their Context in Greco-Roman Antiquity [w:] Global Medieval. Mirrors for Princes Reconsidered (Ilex Foundation Series15), eds. R. Forster, N. Yavari, Boston 2015. 


\section{Bibliografia}

Bielawski J., Klasyczna literatura arabska, Warszawa 1995.

Bielawski J., Lettre d'Aristote à Alexandre le Grand, „Rocznik Orientalistyczny” 1964, 28.

Darling L.T., Mirror for Princes in Europe and the Middle East: A Case of Historiographical Incommensurability [w:] East Meets West in the Middle Ages and Early Modern Times: Transcultural Experiences in the Premodern World, ed. A. Classen, Berlin-Boston 2013.

Haake M., Writing to a Ruler, Speeking to the Ruler, Negotiating the Figure of Ruler: Thoughts on "Monocratological" Texts and their Context in Greco-Roman Antiquity [w:] Global Medieval. Mirrors for Princes Reconsidered (Ilex Foundation Series 15), eds. R. Forster, N. Yavari, Boston 2015.

Ibn 'Abd Rabbih, Al-' Iqd al-farìd, t. I, ed. M.M. Qamīḥa, Bayrūt 1997.

Ibn 'A Abd Rabbih, Al-c'Iqd al-farīd, t. I, ed. M.S. al-cAryān, al-Qāhira 1953.

Ibn 'Abd Rabbihi, Niezwykty naszyjnik, przeł. M.M. Dziekan, wstęp J. Danecki, „Studia Arabistyczne i Islamistyczne” 1996, 4.

Khoury R.G., Wahb b. Munabbih. Der Heidelberger Papyrus PSR Heid Arab 23 (Codices Arabici Antiqui), Wiesbaden 1972.

Lévi-Provençal É., Cywilizacja arabska w Hiszpanii, Warszawa 2006.

London J.A., The Abbasid "Circle of Justice”: Re-reading Ibn al-Muqaffa's Letter of Companionship [w:] Comparative Political Theory in Time and Place, eds. D.J. Kapust, H.M. Kinsella, New York 2017.

Maróth M., Correspondence between Aristotle and Alexander the Great: The Earliest Piece of the Adab-Literature [w:] Proceedings of the 20th Congress of the Union Européenne des Arabisants et Islamisants: Budapest, 10-17 September, t. I, Linguistics, Literature, History, The Arabist, ed. K. Dévényi, Budapest 2002.

Maróth M., The Correspondence between Aristotle and Alexander the Great. An Anonymous Greek Novel in Letters in Arabic Translation, „Acta Antiqua Scientiarum Hungaricae" 2005, 45.

Mojtabā'̄ F., Dāwūd [w:] Encyclopaedia Iranica, t. VII, New York 1994.

Ohlandr E., Enacting Justice, Ensuring Salvation: The Trope of the "Just Ruler" in Some Medieval Islamic Mirrors for Princes, „The Muslim World” 2009, 99/2.

Schmitz M., Kacb al-Ahbār [w:] The Encyclopaedia of Islam, t. IV, Leiden 1997.

The Letter of Tansar, przeł. M. Boyce, Roma 1968.

Toral-Niehoff I., The "Book of the Pearl on the Ruler" in the Unique Necklace by Ibn 'Abd Rabbih [w:] Preliminary Remarks, Global Medieval: Mirrors for Princes Reconsidered, eds. N. Yavari, R. Forster, Cambridge 2016.

Werkmeister W., Quellenuntersuchungen zum "Kitāb al-ciqd al-farīd” des Andalusiers Ibn 'Abdrrabih (246/860-328/940): Ein Beitrag zur Arabischen Literaturgeschichte, Berlin 1983.

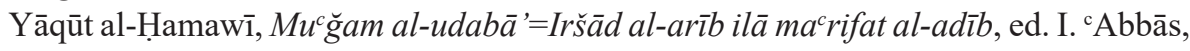
Bayrūt 1993. 